\title{
SECURITISATION: THE CASE OF POST-9/11 UNITED STATES AFRICA POLICY
}

\author{
Robin E Walker and Annette Seegers \\ University of Cape Town
}

\begin{abstract}
In the wake of 9/11, Africa was securitised in a new way by the United States (US): weak states were believed to pose an existential threat to the US. American aid to Africa consequently more than tripled in the years following 9/11. Using the Copenhagen School's securitisation theory, we investigate the interaction between the executive branch as claimant and the US Congress as legitimiser. The factors of political agency and context are accentuated in our use of securitisation theory. Yet, the evidence also points to structural forces, especially the unequal relationship between executive and legislature.
\end{abstract}

\section{Introduction}

After 11 September 2001, the United States' African security agenda changed. Africa became important because weak states were claimed to be a danger to America's security. Unable to provide for the basic needs of their people and lacking full control of their borders, weak states in Africa provided both a breeding ground and safe haven for terrorist organisations.

Who initiated the post-9/11 change in US Africa policy? Why and how did they do so? Who legitimated the claim and why? We address these questions with the help of the Copenhagen School's securitisation theory on account of its analysis of security agenda-setting. ${ }^{2}$ We confine our investigation to the interaction of the executive branch of government and the legislature. The executive contains the head

Scientia Militaria, South African Journal of Military Studies, Vol 40, $\mathrm{Nr} 2,2012$, pp. 22-45. doi: $10.5787 / 40-2-995$ of government, assisted by the civil/public service. The legislative branch here refers to the US Congress, seen here as an institution representing constituents' interests. 
The point of our answers is to illustrate and advance securitisation theory in a way that involves Africa. We try to advance securitisation theory in four ways:

- we provide indicators of successful securitisation, including but going beyond speech acts;

- we show that securitisation processes over time are linked;

- we stress the agency of securitising actors as they manoeuvre in the political process of agenda-setting; and

- we emphasise the historical context within which actors are operating.

In our discussion, we -

- $\quad$ outline the core ingredients of the process of securitisation as understood by the Copenhagen School;

- describe Africa in the pre-9/11 America's security agenda;

- describe the major securitising actors' claims

- $\quad$ analyse congressional responses; and

- $\quad$ provide indicators of Africa's securitisation after 9/11.

A conclusion ends the discussion.

\section{The process of securitisation}

Securitisation theory can be traced back to criticism, most notably first developed by Barry Buzan (1983), that security no longer could be "defined as the threat, use and control of military force" in the hands of states. ${ }^{3}$ If security includes non-military sectors and non-state actors, security agendas however did not consist of a traditional set of issues and sectors but were chosen, constructed or created. Securitisation theory wants to analyse why, by whom and how a non-security issue became a security issue.

Within this ambit, the approach of Critical Security Studies is known to be more cultural in nature, using ideas and habits to explain securitisation. ${ }^{4}$ In the Copenhagen School that emerged in the mid-1990s, one finds, by contrast, a powerful combination of a broad approach to security and Ole Waever's focus on the politics of security. ${ }^{5}$ The Copenhagen School branch of securitisation theory is often used because of its more political approach ${ }^{6}$ to analysing security agendasetting: the focus is on the choices made and actions taken by actors in an attempt to shape and manipulate the security agenda. ${ }^{7}$ 
For the Copenhagen School, the securitising interaction of an actor and an audience is necessary to move an issue from the normal political agenda to the security agenda. This process consists of (1) a securitising claim made by an actor and (2) legitimation by an audience.

The securitisation process begins with an actor claiming that the existence of an object is threatened. The given issue must be portrayed as an existential threat, meaning that if it is not addressed, the referent object is literally destroyed or it is conquered. ${ }^{8}$ To avoid death or domination, measures must be taken and they must be taken immediately, thus moving the issue outside the normal realm of politics and into the extraordinary realm of security. The Copenhagen School conceptualises security, in the first instance, as a speech act: verbal and textual material transmits a threat from actor to audience. ${ }^{9}$

The audience toward which this claim is directed either rejects the claim, thus preventing securitisation, or takes on the argument by echoing the same security language about the issue in question. For legitimation or successful securitisation to occur, a claim must become sufficiently important for an audience. This may be because the claim has been presented as "an existential threat, point of no return, or necessity." 10 Legitimation is further dependent upon context; that is, the conditions that heighten the probability that claims are going to be accepted. Ideological attitudes, trends and views can all help an audience accept a claim. Successful securitisation requires that the claim resonate with the audience in which it resides. ${ }^{11}$

Critics have pointed out that the Copenhagen School does not capture the full complexity of the agenda-setting process. One area of weakness is the simplification of processes of communication. Another weakness lies in the relative indifference to complex institutional interactions and the underplaying of social and political context. ${ }^{12}$ To better capture complexity in the agenda-setting process, we stress agency and context.

\section{Research: question, evidence and method}

We investigate who initiated the post-9/11 change in US Africa policy, why and how they did so, and who legitimated the claims. Taken together, our answers help explain why post 9/11 changes in US Africa policy took place. 
The format of the article is akin to a theoretical case study, with the intent to advance theory and to illustrate a case, and in the belief that the Copenhagen School's approach to securitisation is well suited to the case at hand. Although our method is implicitly comparative, we are unable to investigate alternative or competing explanations of the post-911 securitisation of Africa by the US. We are also unable to investigate whether the US after 911 securitised other parts of the world in a manner similar to Africa; thus, we cannot determine whether the African case fits into a broader pattern of American securitisation.

We use a wide range of evidence to support our arguments. We draw on academic articles and books, reports and Internet sources. Primary sources are however most important, specifically official documents, figures and media statements, for the simple reason that we seek an answer to changes in official US policy.

\section{Securitisation's past}

Throughout the $20^{\text {th }}$ century, American presidents rarely took an interest in Africa, presenting it as having but marginal significance for the US. There were occasional deviations from this view of the security agenda but not many. ${ }^{13}$ During the Cold War, American policy makers united in their view that the primary purpose of the US was to deny the Soviet Union influence in Africa. ${ }^{14}$ Even so, the US stepped back as colonial powers took the lead. When former colonial powers later failed or faltered, Africa could become more significant but even then, executive branch attention would be mediated by the need to placate America's NATO allies. What little strategic significance Africa had was based on the logic of a global geopolitical struggle with the Soviet Union. The Communists could strike anywhere, at any time, and Africa could be one such place. Africa was a means to deny whatever the Soviet Union wanted. ${ }^{15}$

Once the Cold War ended, the US retreated from Africa. ${ }^{16}$ Yet, this retreat was cut short by new claims about the humanitarian necessity to intervene. Humanitarian intervention was not a traditional security issue but one that could, so the claim went, be accomplished by America's unmatched military prowess. The US then backed a 1992 UN humanitarian intervention in Somalia. ${ }^{17}$ The mission's turn for the worse caused American withdrawal. Despite subsequent pressure that the US 
should claim (for example) Burundi, Liberia, Sudan and the former Zaire as security issues, the Americans refused to do so.

The refusal to make a (traditional) security claim about Africa was masked by rhetoric left, right and centre. In 1998, a "new partnership" came between subSaharan Africa (SSA) and the US in which democracy and development would be the guiding principles. In January of the same year, a "Month of Africa" was declared to spotlight pressing issues such as HIV/AIDS and continuing wars. The refusal to make a security claim was also legitimated by the anti-colonial theme of "African solutions to African problems". One illustration of this was the African Crisis Response Initiative (ACRI), a programme to ready African forces for their own peacekeeping. Even this modest programme, intended to keep the US out of SSA, was opposed by Congress. ${ }^{18}$ In 1995, the Department of Defense (DoD) maintained that the US had "very little traditional strategic interest in Africa", ${ }^{19}$ and in the 1998 National Security Strategy's Integrated Regional Approaches to Security, SSA ranked last. ${ }^{20}$ Aid to Africa dropped consistently every year following the end of the Cold War, reaching just below $\$ 700$ million in 2000, well below any other world region. $^{21}$

President George W. Bush entered the White House with every intention of not making a security claim about Africa, as he famously commented on the campaign trail in 2000, "[w]hile Africa may be important, it doesn't fit into the national strategic interests, as far as I can see."22 Yet, for all the American refusals to make security claims about SSA, securitisation in the 1990s did make at least two discursive imprints, visible on the eve of 9/11:

First, some relevance was restored to Africa, albeit a perverse one: Africa was a place where disasters are made. The disasters of the time were conceived as either genocide of the type seen in Rwanda in 1994, or a public health catastrophe as millions died of AIDS. Disasters could not but spill over to others. Furthermore, AIDS deaths would leave communities and countries so devastated that they could not look after themselves, thus requiring intervention. ${ }^{23}$ Second, disasters would drag the US into Africa because it was the only major country with the military and other resources, for example, transport aircraft and aircraft carriers, capable of responding. The US's executive and legislative branches showed great anxiety about being dragged into trouble in this way and devised reasons why it would not get involved. One line of reasoning was to claim Africa's wars were barbaric with the 
desirable conclusion that nobody in their right mind would willingly lower themselves into the "new war" cesspool. Others claimed that, even if the US were prepared to intervene, a mistimed intervention could be ineffective ${ }^{24}$ or make things worse. $^{25}$

\section{Context: 9/11 and the core executive}

A considerable amount of literature has shown how the Bush White House was shocked and surprised by the events of $9 / 11$ but soon also developed considerable cynicism in its response. The moral integrity and sincerity of the actors in the process of securitisation are, however, not at issue here. The more relevant conceptualisation is that the Bush administration developed a set of ideas about 9/11 and how to prevent another 9/11. Why the Bush White House responded as it did has been explained in radically different ways.

One type of explanation stressed impersonal, or structural, factors about the nature of power. Having supposedly bested the Soviet Union in the Cold War, the US inevitably became triumphalist and complacent. Shaken by $9 / 11$, the US overreacted. ${ }^{26}$ Other scholars focused on how the end of the Cold War destabilised America's security paradigms. The War on Terror provided an opportunity to return to old paradigmatic comforts: enemies were everywhere; they could strike at any moment; they could strike with devastating effect, etc. ${ }^{27}$

For many other scholars the claim making of the Bush administration centred on the beliefs of its core members, the Vulcans. They were bound together by similar experiences in their rise to power. Among others, they had been opponents of the Vietnam Syndrome, and would subsequently argue for a more active, executive-driven foreign policy that included the use of war. The events of 9/11 merely provided them with public justification for why this should be so. ${ }^{28}$

Other scholars argue that the Vulcans' personalities mattered more than their beliefs. Much attention was devoted to Vice-President Cheney's authoritarian personality: he saw the nature of executive power as a monarchist and had a history of aggressive attempts at creating that royal power in the US. ${ }^{29}$ Others saw VicePresident Cheney's assertions not as so self-motivated. He became important because of another personality: President George W Bush. Already for reasons of an oedipal conflict believing he needed a crusade comparable to the "greatest" 
American generation's accomplishments in World War II, President Bush manufactured such a mission out of $9 / 11 .^{30}$

Despite the debates over who did what and why, scholars agree the initial definitions of $9 / 11$ contained three points of emphasis. First, an existential threat existed: "The terrorist attacks of September 11, 2001, in Washington, DC, New York City, and Pennsylvania were acts of war against the United States of America and its allies." ${ }^{31}$ National Security advisor Condoleezza Rice, in support, stated, "there is no longer any doubt today that America faces an existential threat to our security - a threat as great as any we faced during the Civil War, World War II, or the Cold War". ${ }^{32}$ Second, the US was entitled to use force: "our response involves far more than instant retaliation and isolated strikes. Americans should not expect one battle, but a lengthy campaign." 33 Both the US government and the American people thought they had been victimised by the surprise nature of the attacks, the killing of unarmed civilians, and the cruelty inflicted on individuals. The victims were politically and morally entitled to respond. Third, Americans were told to prepare themselves for a war anywhere in the world. The early claims of the core executive were desperately short on details. Another layer of claim making about this or that method, opponent, and place would have to follow.

\section{Making claims about Africa: the executive as securitising actor}

Since the early 1980s, policy-makers and scholars in primarily Europe and the UK had started to question the traditional separation of development and security. Although the security-is-development thesis could be intellectually dodgy, for example, in its circular reasoning, it had become accepted by the end of the 1990s. Rather than just providing humanitarian relief when development failed, countries' development failures had to be prevented. If not, their failures would threaten others. ${ }^{34}$

The Vulcans' claims about Africa after 9/11 did not, in other words, emerge out of thin air. The reasoning they were so aggressively trying to promote had been in circulation for some time: Africa was a "disaster". The failed-state idea was irresistible: they generated dangers that were going to be visited upon American people on American soil. ${ }^{35}$ Africa was now a "high priority" on the US security agenda. $^{36}$ The new claim about Africa acquired political ballast through the endorsements of institutions attendant to the core executive. Just two months after 
9/11, the Carnegie Endowment for International Peace (CEIP) held a briefing on "Africa, Islam and Terrorism". 37 The United States Institute of Peace (USIP) issued a special report on "Terrorism in the Horn of Africa". ${ }^{38}$ The Council on Foreign Relations (CFR) established the first Africa policy division of any US think tank, promptly producing a series on the national security implications of the current African condition. ${ }^{39}$ In addition, the Center for Strategic and International Studies (CSIS) reported about the need of a comprehensive security-development approach to underdevelopment in Africa. ${ }^{40}$

Agencies involved in programmes such as African Contingency Training and Assistance (ACOTA), AFRICOM, Foreign Military Financing (FMF) and International Military Education and Training (IMET), were enthusiastic. ${ }^{41}$ The DoD saw Africa developing into a terrorist haven. Extremists were exploiting areas "struggling with resource scarcity, weak national institutions, poverty and inexperienced militaries ... endemic imbalances in the distribution of wealth ... and disenfranchised youth". ${ }^{42}$ The State Department agreed, "Africa today is a place of...severe challenges, such as poverty, disease, terrorism, and instability that all together pose critical risks for US interests." ${ }^{, 43}$ Development aid acquired a similar justification: "Aid is a potent leveraging instrument for keeping countries allied with US policy while they win their own battles against terrorism."44

In the end, just about every African issue became linked to security. ${ }^{45}$ Did the claims about failed states and terror in Africa have validity? As the 9/11 Commission later would show, the US was ill informed and ill prepared about African conditions, including the conditions that would give rise to the use of terror. ${ }^{46}$ However, the core had first access to information, regardless of the quality of that information. Having first access to information, gave the core executive a tremendous advantage in the process of securitisation: when challenged, they could remind their critics that they did not know what they were talking about. What mattered was who possessed information and when.

\section{Context: 9/11 and the Congressional audience}

When the 9/11 attacks occurred, Congress was in session. Between 2001 and 2003, the Democratic and Republican parties were evenly represented in the Senate, with the majorities changing parties on several occasions, but for the remaining time, the Republicans were the majority party. In the House of Representatives, the 
Republican Party was in the majority between 2001 and 2006. In 2006, the Democratic Party gained control of both the House and the Senate. Congress was later to be victimised by letters containing anthrax but by then -9 October $2001-$ Congress had already made their views known. In debates and in legislation (for example, revision of the Patriot Act), members of the US Congress drew parallels between 9/11 and the attack on Pearl Harbour. They referred to Americans' "surprise, unreadiness, and lack of organisation", thus paving the way for new actors and a new discourse to emerge. ${ }^{47}$

Congressional actions were linked to a shift in constituents' views. Numerous publications across disciplines showed that Americans' concern about the threats posed by terror greatly increased with 9/11. Having been shocked, their "political makeup" shifted. ${ }^{48}$ A series of surveys indeed showed that Americans' fear of terror and especially trans-national terror increased to one of the top-ranked security concerns. ${ }^{49}$ Psychological studies conducted after 9/11 showed that the "attacks resulted in immediate and visibly evident increases in expressions of national identification and unity throughout the United States". 50

One obvious reason for the heightened sense of vulnerability was that some of the qualities of the violence on 9/11, for example, fire, is known to alarm people, and another was that the attacks occurred in the least expected place, American soil. The spread of the heightened sense of vulnerability can be also attributed in large part to virtual mobilisation or the creation and manipulation of public opinion through the media, sustained by nearly blanket media coverage. ${ }^{51}$ All four major American news networks (ABC, CBS, NBC and FOX) suspended regular programming and provided uninterrupted coverage for the first five days following the fall of the Twin Towers. ${ }^{52}$ In other parts, the spread of heightened vulnerability had to do with being a participant in 9/11 without having been a direct victim. In the aftermath of 9/11, the NY Stock Exchange's 7-day closure meant financial activity was disrupted on a national scale. Air travel was at first prohibited and then arduous. These measures, however necessary, made many more people feel victimised.

The evidence thus shows that the events of 9/11 had become a major feature of Americans' national frame of reference for security. For legislators, the heightened sense of vulnerability among Americans created a clear cost/benefit ratio: if they opposed measures about security and terror, they would lose political capital. 


\section{Legitimating claims about Africa: the legislature as securitising actor}

How was the legislature persuaded to legitimate the claim made by the core executive? Did contextual factors play any role in this legitimation? We consider legislative approval to determine not only that the requests were authorised, but that the logic behind this authorisation was based on the security-oriented rationale posed by the actors.

Were legislators pushed by their constituents? Did the reasoning of failed African states make terror spread among Americans along with their previously noted rise in a sense of vulnerability? According to our own estimate, printed media 11 September 2001 through 31 December 2007 published 13253 news stories on the subject of Africa. Less than 18 per cent of these were connected with the subject of national security and less than 8 per cent were connected with the subject of terrorism, with the possibility that some of these overlapped, giving stories associated with both subjects double representation. ${ }^{53}$ The lack of Africa coverage may be interpreted in many ways but strongly suggests continued indifference among Americans towards Africa. The inattention to Africa is also certainly connected to views about foreign aid. A Gallup poll conducted from 2002 to 2007 consistently found each year that around $60 \%$ of the population believed that too much foreign aid was being included in the federal budget. ${ }^{54}$

While Congressional hearings held after 9/11 on the subject of Africa stressed security risks emanating from the African continent, the weak-state message found little support in public opinion or, more specifically, the media, even in a period marked by initiatives to bring Africa to the fore, such as "Make poverty history" and the 2005 "Live 8" concert series. This created room for the legislators to bring their own, more personal and political views into the legitimation but still, they faced consistent constituent pressure to endorse the core executive's claims and the new funding proposals.

Did the legislators believe in the post-9/11 reasoning about Africa? Some representatives were vocal but it is impossible to identify personal acceptance of the executive's claims. ${ }^{55}$ Contrastingly, there is abundant evidence that legislators knew of their constituents' greater sensitivity about security and made a habit of inserting references to it in any debate and speech. ${ }^{56}$ In other words, political and indeed electoral interests drove their speech acts. If the legitimation had been turned over to 
the American people, for example in a referendum, the core executive's claim would in all likelihood not have been legitimated. Public opinion remained dead set against foreign aid.

\section{Material consequences}

Military aid

A striking feature of post-9/11 US Africa policy is the increase in military assistance, including military training programmes, regional counterterrorism operations, and the creation of a US military command centre. Military training programmes are managed and funded through the State Department but implemented by the US Department of Defense (DoD). The most prominent of these programmes in post-9/11 African use are IMET, the FMF and the ACOTA programmes. These programmes are intended to educate and train foreign military leaders, provide for their weapons and other equipment acquisition, and build the capacity of African states to respond to crises in their territories. Just three months after 9/11, Congress approved a revision of ACOTA. Originally a programme that trained African forces in "non-lethal" peacekeeping operations, ACOTA became more "robust", and included training in lethal force capabilities. ${ }^{57}$

Military assistance programmes are funded and administered primarily by the DoD with some contribution by State and the CIA. Four major programmes have been created since the 9/11 attacks, intended to enhance the effectiveness of law enforcement and military forces in strategic regions on the continent through direct military-to-military engagement exercises:

- the Combined Joint Task Force - Horn of Africa (CJTF-HOA);

- the Trans-Sahara Counterterrorism Initiative (TSCTI);

- the East Africa Counterterrorism Initiative (EACTI); and

- the Maritime Security Initiative in the Gulf of Guinea, among others. 
Table 1: Military aid: US foreign military aid to sub-Saharan Africa 2001-2006 (in millions) ${ }^{58}$

\begin{tabular}{|l|l|l|l|l|l|l|}
\hline & $\mathbf{2 0 0 1}$ & $\mathbf{2 0 0 2}$ & $\mathbf{2 0 0 3}$ & $\mathbf{2 0 0 4}$ & $\mathbf{2 0 0 5}$ & $\mathbf{2 0 0 6}$ \\
\hline $\begin{array}{l}\text { Regional Defense } \\
\text { Counterterrorism } \\
\text { Fellowship Program }\end{array}$ & 0 & 0 & 95 & 1374 & 1379 & 2400 \\
\hline $\begin{array}{l}\text { Enhanced } \\
\text { international } \\
\text { peacekeeping } \\
\text { capabilities }\end{array}$ & 36 & 5 & 0 & 36 & 0 & 0 \\
\hline $\begin{array}{l}\text { Foreign military } \\
\text { financing }\end{array}$ & 926 & 372 & 1299 & 1126 & 1395 & 4191 \\
\hline $\begin{array}{l}\text { International military } \\
\text { education and training }\end{array}$ & 7332 & 10586 & 9786 & 10168 & 9350 & 9930 \\
\hline $\begin{array}{l}\text { Miscellaneous } \\
\text { military aid }\end{array}$ & 0 & 0 & 0 & 0.3 & 0 & 2262 \\
\hline Unified command & 823 & 2016 & 1717 & 0 & 0 & 2278 \\
\hline $\begin{array}{l}\text { Peacekeeping } \\
\text { operations* }\end{array}$ & 47 & 55 & 78 & 30 & 199 & 232 \\
\hline $\begin{array}{l}\text { Regional Center for } \\
\text { Security Studies }\end{array}$ & 553 & 2264 & 2044 & 2618 & 4545 & 3084 \\
\hline $\begin{array}{l}\text { Service-sponsored } \\
\text { activities }\end{array}$ & 261 & 355 & 1233 & 519 & 569 & 766 \\
\hline TOTAL & 9978 & 15653 & 16252 & 15871 & 17437 & 25143 \\
\hline
\end{tabular}

*ACOTA funding through peacekeeping operations taken from United States Department of State, 2007.

A US military command centre for Africa was announced in February 2007. This would create a regional command for Africa comparable to those for Europe and the Pacific. Congress approved the new command centre. The African Command (AFRICOM) is staffed by high-level officials from the Department of State and USAID in addition to the DoD. This is not unusual; other regional commands also have political officials as advisors. What is exceptional about AFRICOM is the extent of these officials' involvement. A senior US diplomat 
serves as Deputy to the Commander for Civil-Military Affairs (DCMA), ranked at the same level as the DoD's Deputy to the Commander for Military Operations (DCMO). Alongside the DCMO, this diplomat manages programmes associated with "non-traditional" security-related issues such as de-mining, disaster response, security sector reform, and peace support operations. ${ }^{59}$

As is evident in Table 1, US military aid to SSA increased dramatically as Congress funded the requests of the Bush administration about US national security needs on the African continent.

\section{Development aid}

After 9/11, three new developmental programmes were developed, each justified as being a necessary measure to reduce the terrorism security threat. Two of these programmes, the President's Emergency Plan for AIDS Relief (PEPFAR) and the Millennium Challenge Account (MCA) were primarily focused on Africa. The third programme, the African Growth and Opportunity Act (AGOA), was begun during the Clinton administration but extended during the Bush administration. In numerical terms, the total amount of official aid (or ODA) provided to sub-Saharan Africa comes from a range of accounts, including PEPFAR, the MCA, AGOA but also the Economic Support Fund, Child Survival and Health, and Food for Education, etc.

As is evident from Table 2, ODA received a substantial boost in the years following 9/11, going up from $\$ 1.3$ billion in 2001 to $\$ 4.6$ billion in 2007:

Table 2. Development aid: official development assistance to sub-Saharan Africa (in millions) ${ }^{60}$

\begin{tabular}{|l|l|l|l|l|l|l|}
\hline $\mathbf{2 0 0 1}$ & $\mathbf{2 0 0 2}$ & $\mathbf{2 0 0 3}$ & $\mathbf{2 0 0 4}$ & $\mathbf{2 0 0 5}$ & $\mathbf{2 0 0 6}$ & $\mathbf{2 0 0 7}$ \\
\hline 1375,77 & 2372,29 & 4642,58 & 3504,05 & 4065,02 & 5602,85 & 4567,8 \\
\hline
\end{tabular}

AGOA and the expanded US-Africa trade initiative enjoyed widespread Congressional support after 9/11. Originally set to expire in 2008, AGOA has been extended to run through to $2015 .^{61}$ 
Table 3. Development Aid: Millennium Challenge Account (in USD millions) ${ }^{62}$

\begin{tabular}{|l|l|l|l|}
\hline $\mathbf{2 0 0 4}$ & $\mathbf{2 0 0 5}$ & $\mathbf{2 0 0 6}$ & $\mathbf{2 0 0 7}$ \\
\hline 994 & 1488 & 1752.3 & 1752.3 \\
\hline
\end{tabular}

Note: Numbers represent total MCA funding; not available by geographic region.

As can be seen in Tables 3 and 4, Congress also authorised both the MCA and PEPFAR. These programmes have seen substantial increases in assistance to Africa. While the appropriations numbers are not reported according to geographic region, a solid majority of both accounts' resources go to sub-Saharan Africa, as intended in their inception. ${ }^{63}$

Table 4. Development aid: global HIV/AIDS funding/PEPFAR (in millions) ${ }^{64}$

\begin{tabular}{|l|l|l|l|l|l|l|}
\hline 2001 & $\mathbf{2 0 0 2}$ & $\mathbf{2 0 0 3}$ & $\mathbf{2 0 0 4}$ & $\mathbf{2 0 0 5}$ & $\mathbf{2 0 0 6}$ & $\mathbf{2 0 0 7}$ \\
\hline 840 & 1200 & 1500 & 2300 & 2700 & 3300 & 4500 \\
\hline
\end{tabular}

Note: PEPFAR appropriations begin Financial Year 2004 (FY2004)

\section{Institutional consequences: jurisdictional expansion}

After 9/11, US Africa policy saw increasing DoD control over what had been a Department of State-managed aid structure implemented by military personnel. The new training programmes under direct DoD management allowed the DoD to bypass both State Department and Congressional oversight stipulations. ${ }^{65}$

The Regional Defense Counterterrorism Fellowship Program (CTFP) was initially authorised by Congress in 2002 as a temporary DoD appropriation for education in strategy and doctrine provided by the US to foreign militaries, but was granted permanent authorisation and legal status the following year, making the programme the same as the State Department-funded IMET programme. ${ }^{66}$ The significance of the CTFP's funding through the DoD as opposed to the State Department is seen in its avoidance of legal restrictions imposed on IMET 
concerning eligible participants, in effect opening up the same training provisions to those agents barred from IMET.

The DoD similarly sought to circumvent the American Service-members' Protection Act (ASPA). ASPA prohibits military engagement with countries that had not signed a bilateral agreement with the US guaranteeing that Americans will not be transferred to the International Criminal Court. The Bush administration issued 17 waivers to African countries during the period of this study. ${ }^{67}$ In 2006 , Congress rescinded the restriction on IMET training. ${ }^{68}$

The same process repeated itself over Section 1206, originally a temporary provision for the DoD to fund Iraqi and Afghan military training without the involvement of the State Department. At that time, war-time need was said to justify circumvention of time-consuming State Department processes. ${ }^{69}$ In 2006, other countries' military training needs led Congress to approve the DoD as sole authority to plan, implement and fund those programmes through DoD-accounts. ${ }^{70}$ Since the inception of the expanded Section 1206, Africa has already seen significant growth in its share of the funding as evidenced by the jump from $\$ 13$ million in 2006 to $\$ 44.9$ million in 2007 . These funds are used in military training and counterterrorism operations accounts. $^{71}$

The changes in the US Africa development aid structure also witnessed a loss of State Department and USAID power to the DoD. In the ODA, the distribution of aid - who gets what - is striking. One study reported that ODA increases were being used to increase military sectors in "either petroleum exporting countries or countries whose support had been enlisted in the USWOT, such as Nigeria, Angola, Ethiopia, Kenya and Sudan". ${ }^{72}$ Another study noted that nontraditional military aid conducted through accounts such as Section 1206 was augmenting military aid; the share of ODA assistance provided through the DoD rather than USAID or State, for example, had gone from 5.6 per cent in 2002 to 21.7 per cent in 2005 . $^{73}$

\section{Speech-acts as consequences: existential threats to the US from Africa}

Previously framed as a humanitarian concern with little relevance to American security, Africa has been reframed as a place where underdevelopment created desperate populations vulnerable to the promises of extremists and where 
weak governments are unable to detect or apprehend those extremists. In Africa, promise and opportunity sit side by side with disease, war and desperate poverty. This threatens both a core value of the United States - preserving human dignity and our strategic priority - combating global terror ... [the United States] must help strengthen Africa's fragile states, help build indigenous capability to secure porous borders, and help build up the law enforcement and intelligence infrastructure to deny havens for terrorists. ${ }^{74}$

The Department of Defense introduced its post-9/11 National Military Strategy with reference to the threat emanating from the African continent: "adversaries take advantage of ungoverned space and under-governed territories from which they prepare plans, train forces and launch attacks". ${ }^{75}$ These claims have been sustained for many years. In 2006, for example, Secretary of State Condoleezza Rice still insisted:

It was ... (once) assumed that weak and poorly governed states were merely a burden to their people, or at most, an international humanitarian concern but never a true security threat. Today ... geographic regions are growing ever more integrated economically, politically and culturally. This creates new opportunities but it also presents new challenges, especially from transnational threats like terrorism ... ${ }^{76}$

The portrayal of Africa as a threat to the US has support in Congress and thus, by implication, of the America people. Legislators directly and usually without qualification have endorsed the core executive's claims about weak African states:

It is clear that in the fight against terrorism, no region can be ignored, and that is especially true of Africa. The general weakness of African governments, as well as the civil strife which exists in several countries, makes parts of the continent hospitable grounds for terrorist operations. ${ }^{77}$

Having previously claimed that failing states pose dangers for intervention, post-9/11 claims were that failed states generated dangers that were going to be visited upon American people at home. 


\section{Conclusion}

How was Africa securitised after 9/11? We considered only the executive and the legislature in our investigation. Who initiated claims, how and why? And who legitimated the claims, how and why?

The US core executive initiated the process after 9/11, claiming that African underdevelopment represented an existential threat to Americans. Unable to provide for the basic needs of their people and lacking full control of their borders, weak states provide both a breeding ground and safe haven for terrorist organisations. Congress legitimated these claims by creating programmes or funding programmes for a War on Terror in Africa.

However complex the interaction between the claimant (the core executive) and the legitimiser (the legislature) became, the political advantage clearly belonged to the core executive. The core executive defined the threat and how they did so was determined by key individuals in an epistemic community. This epistemic community's views of the causes of terror were not necessarily valid but the core executive's claim had acquired political ballast through the executive's early and privileged access to information. The core executive also had rewards, like money and status, to attach to those who accepted their claims. When the claims reached the audience, the US Congress, the legislators were reacting to the core executive's claims: the legitimiser was not an entity capable of interaction with the core executive on an equal footing. Although we have examined one case only, it is likely that the unequal interaction is structural in nature and therefore probably present in other comparable cases.

The attacks of $9 / 11$ created a context. In the light of their constituents' heightened fears, the congressional legitimisers were keen to display an awareness of security, mentioning it wherever they could. Some legislators were quite vocal in repeating the reasoning of the core executive. And with great regularity the legislators deferred to - legitimated - the core executive's requests. The majority of American voters remain opposed to foreign aid, regardless of how it is dressed up, and greater public involvement probably would result in failed securitisation. Why legislators endorse the core executive's claims in all likelihood derived from being intimidated by the core executive or from their fear of losing political capital with their constituents. 
From a more theoretical perspective, this case suggests greater attention be paid in the structural positions of actors in the process of securitisation. Within government, the core executive enjoys immeasurable advantages. The legislature as legitimiser seems destined to play the role of reactor, with all the disadvantages that arriving second entails.

\section{Endnotes}

${ }^{1}$ This article is in large part based on Walker, RE. "Securitisation: The case of post 9/11 United States Africa policy". MA-thesis. University of Cape Town, 2009. We thank the examiners, professors Antoinette Handley and Heidi Hudson, and the reviewers for their helpful comments and suggestions.

${ }^{2}$ Buzan, B. 1983, as cited in Walt, S. "The Renaissance of Security Studies". International Studies Quarterly 35/2. 1991. 212.

${ }^{3}$ Ibid.

${ }^{4}$ Krause, K \& Williams, MC (eds), Critical Security Studies. Minneapolis, MN: University of Minnesota Press, 1997.

${ }^{5}$ Waever, O. Security, the Speech Act: Analyzing the politics of a word. Working Paper No. 19. Copenhagen: Center for Peace and Conflict Research, 1989; Waever, O. "Securitization and desecuritization". In: Lipshutz, RD (ed), On security, New York: Columbia University Press, 1995, 46-86.

${ }^{6}$ As compared to, for example, the cultural approach of Vivienne Jabri. See Vivienne, Discourses on Violence: Conflict Analysis Reconsidered, Manchester: Manchester UP, 1996, 29-53.

${ }^{7}$ Buzan, B, Waever, O \& De Wilde, J. Security: A new framework for analysis. Covent Garden: Lynne Rienner, 1998.

${ }^{8}$ Ibid., p. 24.

${ }^{9}$ Ibid., pp. $25-44$.

${ }^{10}$ Ibid., p. 25.

${ }^{11}$ Balzacq, T. "The three faces of securitization: Political agency, audience and context”. European Journal of International Relations 11/2. 2005. 183-186.

12 Ibid., pp. 171-201; McDonald, M. "The Copenhagen School and the construction of security". Paper presented at the $48^{\text {th }}$ Annual International Studies Association Convention, Chicago, 27 February - 3 March 2007. 7; Williams, MC. "Words, images, enemies: Securitization and international politics". International Studies Quarterly 47. 2003. 528.

13 Alden, C. "From neglect to 'virtual engagement': The United States and its new paradigm for Africa”. African Affairs 99. 2001. 355; Schraeder, PJ. "Speaking with many voices: Continuity and change in US Africa policies". The Journal of Modern African Studies 29/3. September 1991. 373-376; 
Ugboaja Ohaegbulam, F. US policy in postcolonial Africa: Four case studies in conflict resolution. New York: Peter Lang, 2004, 7-8, 51.

${ }^{14}$ Hoffman, S. "What Should We Do in the World?" The Atlantic Monthly 264/4. October 1989. 84-96.

${ }^{15}$ Ugboaja Ohaegbulam op cit, p. 9.

${ }^{16}$ Michaels, M. "Retreat from Africa”. Foreign Affairs 72/1. 1993. 94.

${ }^{17}$ Lawson, L. "US Africa policy since the Cold War". Strategic Insights 4/1. January 2007. <www.ccc.nps.navy.mil/si/2007/Jan/lawsonJan07.asp> Accessed on 24 October 2012.

${ }^{18}$ Hirsh, M. "Calling all regio-ops: Peacekeeping's hybrid future”. Foreign Affairs 79/6. November/December 2000. 2-3; Lawson op. cit.

${ }^{19}$ United States Department of Defense, Office of International Security Affairs. US security strategy for sub-Saharan Africa. Washington, DC: Office of International Security Affairs, 1995, p. 3.

${ }^{20}$ President of the United States of America. A national security strategy for a new century, October 1998.

${ }^{21}$ United States Department of State, 2000. http://www.state.gov/documents/organization/100326.pdf Accessed on 24 October 2012.

${ }^{22}$ Fisher, I. "Africans Ask if Washington's Sun Will Shine on Them," The New York Times, February 8, 2001. A3.

${ }^{23}$ Lyman, PN. "Introduction”. In: Lyman, PN \& Dorff, P (eds), Beyond humanitarianism: What you need to know about Africa and why it matters, New York: Council on Foreign Relations, 2007, p. ix.

${ }^{24}$ Zartman, IW. Ripe for resolution: Conflict and intervention in Africa. Oxford: Oxford University Press, 1989.

${ }^{25}$ Ignatieff, M. The warrior's honor. New York: Henry Holt, 1998, 72-108.

${ }^{26}$ Isikoff, M \& Corn, D. Hubris, the inside spin, scandal and the selling of the Iraq War. New York: Crown Publishers, 2006.

${ }^{27}$ For example Buzan, B. "Will the 'global war on terrorism' be the new Cold War?” International Affairs 82/6. 2006. 1102.

${ }^{28}$ Mann, J. The rise of the Vulcans: The history of Bush's War Cabinet. New York: Penguin, 2004; Yoo, J. War by other means: An insider's account of the war on terror. New York: Atlantic Monthly Press, 2006.

${ }^{29}$ Cheney, R, Vice-President of the United States of America. Remarks before the Council on Foreign Relations. New York City, 16 February 2002.

${ }^{30}$ Burbach, R \& Tarbell, J. Imperial overstretch: George W Bush and the hubris of empire. London: Zed Books, 2004; Gellman, B. Angler the Cheney Vice Presidency. New York: Penguin, 2008; Weisberg, J. The Bush tragedy. New York: Random House, 2008.

${ }^{31}$ President of the United States of America. National strategy for combating terrorism, February, 2003, 1. 
${ }^{32}$ Rice, $C$, cited in Leffler, MF. " $9 / 11$ and the past and future of American foreign policy". International Affairs 79/5. 2003. 1049.

${ }^{33}$ President of the United States of America. Address to a joint session of Congress and the American people, 20 September 2001.

${ }^{34}$ Duffield, M. Global governance and the new wars: The merging of development and security. New York: St. Martin's Press, 2001, 1-15.

${ }^{35}$ President of the United States of America. National security strategy of the United States of America, September 2002, Introduction; 10-11.

${ }^{36}$ President of the United States of America. Memorandum waiving prohibition on United Sates Military assistance to parties to the Rome Statute establishing the International Criminal Court, 29 September, 2006, 37.

${ }^{37}$ Carnegie Endowment for International Peace. Africa, Islam and terrorism. Briefing Event, 27 November 2001.

${ }^{38}$ United States Institute of Peace. Terrorism in the Horn of Africa. Special Report 113, January 2004.

${ }^{39}$ Lyman op. cit.

${ }^{40}$ Center for Strategic and International Studies. Integrating $21^{\text {st }}$ century development and security assistance. Final report of the Task Force on Nontraditional Security Assistance, January 2008, vi.

${ }^{41}$ Allen, M. "Inaction is not an option: Bush offers military aid in continuing war on terror". Washington Post. 12 March 2002. A1.

${ }^{42}$ Tallent, HB. Director, United States Military European Command Center. Statement to the House. Subcommittee on International Terrorism, Nonproliferation and Human Rights. Eliminating Terrorist Sanctuaries. 109th Congress, 10 March 2005.

${ }^{43}$ Mull, S. Acting Assistant Secretary of State of Political-Military Affairs, Department of State. Statement to the House Committee of Armed Services. US Africa Command. 110th Congress, 14 November 2007.

${ }^{44}$ United States Agency for International Development. Foreign aid in the national interest: Promoting freedom, security and opportunity, 2002, 3.

${ }^{45}$ Center for Strategic and International Studies. Advancing US leadership on global HIV/Aids: Opportunities in the PEPFAR reauthorization process. Report of the HIV/Aids Task Force, May 2007, 3; Lyman, PN, Senior Fellow and Director of Africa Policy Studies, Council on Foreign Relations. Statement to the Senate. Committee on Foreign Relations. Halting the global spread of HIV/Aids: The future of US bilateral and multilateral responses. 107th Congress, 13 February 2002; United States Institute of Peace. Aids and violent conflict in Africa. Special Report 75, October 2001.

${ }^{46}$ United States National Commission on Terrorist Attacks upon the United States. The 9/11 Commission Report, July 2004, 108-144; Congressional Research Service Report for Congress. Africa and the war on terrorism. The Library of Congress, 17 January 2002, 5-6. 
${ }^{47}$ Mabee, B. "Re-imagining the borders of US Security after 9/11: Securitization, risk, and the creation of the Department of Homeland Security". Globalizations 4/3. September 2007. 389.

${ }^{48}$ Gaddis, JL. Surprise, security and the American experience. New Haven, CT: Yale University Press, 2004, 4-5.

${ }^{49}$ For instance, Pew Research Center for the People and the Press. Public more internationalist than in the 1990s: Terrorism worries spike, war support steady. Survey report, 12 December 2002; Shambaugh, G. "A portrait of America in turbulent times: Public perceptions and the political salience of terrorism and other traumatic events". Paper presented to Institute for Global and International Studies, Elliott School of International Affairs, The George Washington University, Washington, DC, 25 September 2008.

${ }^{50} \mathrm{Li}, \mathrm{Q} \&$ Brewer, MB. "What does it mean to be an American? Patriotism, nationalism and American identity after 9/11". Political Psychology 25/5. October 2004. 728. See also Carroll, PJ, Wichman, AL \& Arkin, RM. "Security in the aftermath of 9/11". Basic and Applied Social Psychology 28/4. 2006. 289-290; Schilkraut, DJ. "The more things change ... American identity and mass and elite responses to 9/11". Political Psychology 23/3. September 2002. 511-535; Silver, RX; Holman, EA; McIntosh, DN; Poulin, M; and Gil-Rivas, V. "Nationwide Longitudinal Study of Psychological Responses to September 11." The Journal of the American Medical Association. 288/20. September 11, 2002: 1235-1244.

${ }^{51}$ Ignatieff, M. Virtual war. New York: Henry Holt, 2002, 176-191.

${ }^{52}$ Denton, Jr, RE. Language, symbols, and the media: Communication in the aftermath of the World Trade Center attack. New Brunswick: Transaction Publishers, 2004, 3.

${ }^{53}$ Using LexisNexis Media, we conducted a search for "Africa" in the headlines of the New York Times, New York Post and Washington Post. Results were then sorted according to their listed subject tags as either "national security" or "terrorism" as provided by LexisNexis Media. This search was repeated with the name of every country in sub-Saharan Africa in order to ensure no possible Africa-related stories were missed should "Africa" not appear in the headline. Our evidence here is suggestive, as the three newspapers are not a representative sample.

${ }^{54}$ By year, the results were $63 \%$ in $2007,64 \%$ in $2006,54 \%$ in $2005,60 \%$ in 2004 , 2003 was not included in the Gallup Poll publication, 53\% in 2002. News Service. "World Affairs Survey". Gallup Polls Social Series, 2002-2006.

${ }^{55}$ Green, M, US Representative, US House of Representatives. Statement to the House. Committee on International Relations. Implementation of the Millennium Challenge Act. 108th Congress, 19 May 2004; Hyde, H, US Representative, US House of Representatives. Statement to the House. Committee on International Relations. Global effort to combat HIV/Aids. 
108th Congress, 4 May 2004; Lee, B, US Representative, US House of Representatives. Statement to the House. Subcommittee on Africa. African terrorism. 108th Congress, 1 April 2004; Lugar, R, US Senator, US Senate. Statement to the Senate. Committee on Foreign Relations. Commission on Africa Report. 109th Congress, 17 May 2005; Payne, DM, US Representative, US House of Representatives. Statement to the House. Subcommittee on Africa. African terrorism. 108th Congress, 1 April 2004; Royce, ER, US Representative, US House of Representatives. Statement to the House. Subcommittee on Africa. African terrorism. 108th Congress, 1 April 2004; Royce, ER, US Representative, US House of Representatives. Statement to the House. Subcommittee on Africa. African Growth and Opportunity Act. 108th Congress, 11 May 2004.

${ }^{56}$ For example Feingold, R, US Senator, US Senate. Statement to the Senate. Committee on Foreign Relations. Foreign Assistance Programs for Africa. 108th Congress, 2 April 2003; Kolbe, J, US Representative, US House of Representatives. Statement to the House. Subcommittee on Foreign Operations, Export Financing and Related Programs. FY 2003 appropriations for security assistance (military aid) and other assistance to front-line states in the war on terrorism. 108th Congress, 18 April 2003; Lowey, NM, US Representative, US House of Representatives. Statement to the House. Subcommittee on Foreign Operations, Export Financing and Related, 2003; Lugar, R, US Senator, US Senate. Statement to the Senate. Committee on Foreign Relations. Commission on Africa Report. 109th Congress, 17 May 2005; Millender-McDonald, J, US Representative. Statement to the House. Subcommittee on Foreign Operations. FY 2004 appropriations requests by members. 108th Congress, 2 April 2003; Royce, ER, US Representative, US House of Representatives. Statement to the House. Subcommittee on Africa. Africa and the war on terror. 107th Congress, 15 November 2001.

${ }^{57}$ We place non-lethal in quotation marks because even from the start, both ACOTA and ACRI stressed basic training, including the use of force.

${ }^{58}$ United States Department of State, 2006. FY 2007 numbers not yet available at the time of this study.

${ }^{59}$ United States Africa Command. Biographies: Ambassador Mary Carlin Yates, Deputy to the Commander for Civil-Military Activities. Department of Defense. 2009. <http://www.africom.mil/yates.asp > Accessed on 15 November 2009.

${ }^{60}$ OECD DAC Aid Statistics. <www.oecd.org/dac/stats> Accessed on 15 November 2009.

${ }^{61}$ African Growth and Opportunity Act. Info. About AGOA. 2008. <http://www.agoa.info/index.php?view=about\&story=about $>$ Accessed on 15 November 2009; Congressional Research Service Report for Congress. 
US trade and investment relationship with sub-Saharan Africa: The African Growth and Opportunity Act and beyond. The Library of Congress, Updated 28 October 2008.

${ }^{62}$ SOURCE: Department of State Function 150 Congressional Budget Justification FY2006-2009 (Actual aid numbers confirmed 2 years after disbursed.) Note: Numbers are total MCA funding; not available by geographic region.

${ }^{63}$ Congressional Research Service Report for Congress. Millennium challenge account. The Library of Congress. Updated 8 October 2008. Available at http://www.legistorm.com/score_crs/show/id/121616.html Accessed 24 October 2012.

${ }^{64}$ PEPFAR. Making a difference: Funding fact sheet . <http://www.pepfar.gov/press/80064.htm> Accessed on 24 October 2012.

65 The term 'bypass' does not suggest the DOD is acting illegally. Waivers are part of the ASPA legislation and using them means following the legislation.

${ }^{66}$ Congressional Research Service Report for Congress. The Department of Defense role in foreign assistance: Background, major issues, and options for Congress. The Library of Congress, 25 August 2008.

67 The 30 June 2003 directive included waivers for Djibouti, DRC, Ghana, Botswana, Nigeria and Uganda; the 24 September 2003 directive included a waiver for Guinea; the 29 September 2006 directive included waivers for Kenya, Mali, Namibia, Niger, South Africa and Tanzania; and the 27 November 2006 directive again included waivers for Kenya, Mali, Namibia, Niger, South Africa and Tanzania.

${ }^{68}$ United States Congress, House of Representatives. National Defense Authorization Act for FY 2007. Title XII: Matters Relating to Foreign Nations. House Report 109-452, 2007, 38.

${ }^{69}$ Congressional Research Service Report for Congress. Africa: US foreign assistance issues. The Library of Congress, 28 July 2006.

${ }^{70}$ Only in selected programs and countries must the DOD acquire the approval of the State Department. Rice, C. Secretary of State. Joint Statement to the House with Secretary of Defense Robert Gates. Armed Services Committee. Building Partnership Capacity and Development of the Interagency Process. 110th Congress. August 15, 2008.

${ }^{71}$ Congressional Research Service Report for Congress. Section 1206 of the National Defense Authorization Act for FY2006: A fact sheet on Department of Defense authority to train and equip foreign military forces, 15 May 2008.

72 Organization for Economic Cooperation and Development, 2005, cited in Aning, K. "Security, the war on terror and official development assistance". Paper prepared for the project Southern Perspectives on Reform of the International Development Architecture, Kofi Annan International Peacekeeping Training Center, Accra, Ghana, September 2007, 14. 
${ }^{73}$ Center for Strategic and International Studies. Integrating $21^{\text {st }}$ century ... op . cit., p. vi.

${ }^{74}$ President of the United States of America. National security strategy of the United States of America, September 2002, 10-11.

${ }^{75}$ United States Department of Defense. National Military strategy for the United States of America: A strategy for today; a vision for tomorrow, 2004, iii.

${ }^{76}$ Rice, C. Secretary of State. "Remarks on transformational diplomacy".

Georgetown University, Washington, DC, 18 January 2006.

${ }^{77}$ Royce, Africa and the war on terror, op. cit. 